\title{
Environmental implications of biohydrogen based energy production from steam reforming of alcoholic waste
}

Antonio Cortés, Gumersindo Feijoo, Antonio Chica, Javier Francisco Da Costa-Serra, María Teresa Moreira

\section{Accepted Mansucript}

\section{How to cite:}

Cortés, A., Feijoo, G., Chica, A., Da Costa-Serra, J., \& Moreira, M. (2019). Environmental implications of biohydrogen based energy production from steam reforming of alcoholic waste. Industrial Crops And Products, 138, 111465. doi: 10.1016/j.indcrop.2019.111465

\section{Copyright information:}

(C) 2019 Elsevier Ltd. This manuscript version is made available under the CC-BY-NC-ND 4.0 license (http://creativecommons.org/licenses/by-nc-nd/4.0/) 
Environmental implications of biohydrogen based energy production from steam reforming of alcoholic waste

\section{Antonio Cortés ${ }^{\mathrm{a}}$, Gumersindo Feijoo ${ }^{\mathrm{a}}$, Antonio Chica ${ }^{\mathrm{b}}$, Javier Francisco Da Costa-Serra ${ }^{\mathrm{b}}$ and María Teresa Moreira ${ }^{a^{*}}$}

${ }^{a}$ Department of Chemical Engineering, School of Engineering, Universidade de Santiago de Compostela, Rúa Lope Gómez de Marzoa, s/n, 15782 Santiago de Compostela (Spain)

${ }^{b}$ Institute of Chemical Technology, Universitat Politècnica de València-Consejo Superior de Investigaciones Científicas, Avd. de los Naranjos s/n, 46022 València (Spain)

${ }^{*}$ Corresponding author

E-mail: maite.moreira@usc.es

\section{Abstract}

Nowadays, there is an increasing demand for energy in the world. With an energy system still based on fossil fuels, a paradigm shifts towards clean energy production based on available renewable resources is necessary. Hydrogen is a high-quality energy carrier that can be used with great efficiency and is expected to acquire a great importance in the next generation of fuels. This study aims to analyze the potential environmental impacts associated with the steam reforming of alcoholic waste from distilleries to produce clean electricity by using the Life Cycle Assessment methodology. The main findings from this study reported that the global environmental profile is better than other alternatives more common as sanitary landfill or incineration. In terms of some impact categories as Abiotic and Ozone Depletion, Acidification and Eutrophication, steam reforming of alcoholic waste performed better profiles than other processes that produce hydrogen from diverse feedstocks.

Keywords: Alcoholic waste; Environmental profile; LCA; SOFC; Biohydrogen 


$\begin{array}{ll}\text { LCA } & \text { Life Cycle Assessment } \\ \text { SS } & \text { Subsystem } \\ \text { CC } & \text { Climate change } \\ \text { OD } & \text { Ozone depletion } \\ \text { TA } & \text { Terrestrial acidification } \\ \text { FE } & \text { Freshwater eutrophication } \\ \text { ME } & \text { Marine eutrophication } \\ \text { HT } & \text { Human toxicity } \\ \text { POF } & \text { Photochemical oxidant formation } \\ \text { PMF } & \text { Particulate matter formation } \\ \text { TET } & \text { Terrestrial ecotoxicity } \\ \text { FET } & \text { Freshwater ecotoxicity } \\ \text { MET } & \text { Marine ecotoxicity } \\ \text { FD } & \text { Fossil depletion } \\ \text { WW } & \text { Wastewater } \\ \text { WGS } & \text { Water Gas Shift } \\ \text { PSA } & \text { Pressure Swing Adsorption } \\ \text { ISO } & \text { International Organization for Standardization }\end{array}$

28 Currently, global energy production is based on the use of fossil fuels such as coal, oil and

29 natural gas (Rossetti et al., 2015a) and accounts for approximately 65\% of global GHG

30 emissions (Uusitalo et al., 2017). Dependence on the use of fossil fuels as an energy resource

31 has caused environmental problems of global impact, such as air pollution in terms of emission

32 of pollutants and particles, as well as the depletion of natural resources, among others (Hajjaji

33 et al., 2016; Reyes-Valle et al., 2015), which leads to adverse consequences for society in terms

34 of human health and damage to the ecosystem (Valente et al., 2019). So much so that the

352030 Agenda and the 17 Sustainable Development Goals (SDGs) set by the United Nations 
includes ensuring access to affordable, reliable and sustainable energy for all. This objective aims at guaranteeing universal access to energy service, substantially increasing the share of renewable energy in the global energy mix and doubling the rate of improvement in energy efficiency. This is why the paradigm shift towards clean energy production must be based on available renewable resources (Da Costa-Serra and Chica, 2018).

In recent years, numerous alternatives to the use of traditional fossil fuels have been proposed, such as the production of biofuels, bioalcohols, hydrogen or any type of renewable energy (Balat, 2011). In particular, biomass is one of the renewable energy sources that has experienced strong growth in recent years, due to its global availability and diversity (Spiridon et al., 2016; Tian et al., 2018). Biofuels derived from biomass offer a number of advantages over their oil-based counterparts according to Demirbas (2008): they can be considered carbon neutral after-combustion by fixing carbon during biomass growth, close to a carbon-neutral balance, so that they contribute to achieving sustainability goals. For this reason, numerous initiatives have been developed in the development of conversion technologies based on resources derived from biomass (Unrean et al., 2018).

Focusing on the different types of fuels, hydrogen is a high quality energy carrier that can be used with high efficiency (Frolov et al., 2013) and is expected to acquire great importance in next generation fuels (Alipour-Moghadam et al., 2014). This fact, together with declining fossil fuel reserves, steadily rising prices and increasing pollution make hydrogen a very attractive product for meeting global energy demand (Khaodee et al., 2011).

However, the environmental profile of hydrogen-based energy systems is as "clean" or "dirty" depending on the scheme of conversion (Rabenstein and Hacker, 2008). The traditional schemes producing $\mathrm{H}_{2}$ from natural gas are a major source of $\mathrm{CO}_{2}$, with emissions of approximately 10-12 $\mathrm{kg}$ of $\mathrm{CO}_{2}$ per $\mathrm{kg}$ of $\mathrm{H}_{2}$ (Spath and Mann, 2001). Traditional plants produce hydrogen by catalytic steam reforming of natural gas, which is a mature technology and is the 
pathway by which most hydrogen is produced today. Because of this, reducing $\mathrm{CO}_{2}$ emissions associated with hydrogen production would result in a considerable reduction of pollution (Salkuyeh et al., 2018).

In this sense, fuel cells technology and the use of hydrogen are proposed as one of the most promising environmental solutions in relation to the reduction of global emissions (Díaz Alvarado and Gracia, 2010). Fuel cells are devices that electrochemically convert chemical energy from fuels into electricity (Morales et al., 2010). Among the different types of fuel cells, the Solid Oxide Fuel Cell (SOFC) is the most efficient, due to its high operating temperatures and the fact that it is not poisoned with CO (Hernández and Kafarov, 2009). When this type of battery is used, an efficiency around 50\% can be obtained (Strazza et al., 2015); in addition, an efficiency of $70 \%$ can be achieved if cogeneration system is used (Strazza et al., 2010).

Hydrogen production from renewable sources such as poplar (Susmozas et al., 2016) or willow wood (González-García et al., 2012), sugar cane (Halleux et al., 2008), sweet potato (Costa et al., 2018), sorghum (Aguilar-Sánchez et al., 2018) or sugar beet (Luo et al., 2009) have been investigated as the first actions to achieve a significant reduction of environmental impacts (Salkuyeh et al., 2018). Hydrogen can be obtained from different feedstocks through steam reforming (Braga et al., 2016; López et al., 2019; Zheng et al., 2019), autothermal reforming (Khila et al., 2017; Spallina et al., 2018; Xue et al., 2017) and aqueous phase reforming (Coronado et al., 2018; Esteve-Adell et al., 2017; García et al., 2018), among them, steam reforming is the most common, as almost $90 \%$ of $\mathrm{H}_{2}$ is produced by natural gas reforming. It also has the highest conversion efficiency, around 70\% (Haryanto et al., 2005).

Steam reforming of natural gas is the most popular method for producing commercial hydrogen that currently covers about $50 \%$ of global hydrogen demand (Anzelmo et al., 2018) and is sometimes referred to as steam methane reforming (SMR). Steam reforming is an endothermic process based on the reaction of gas with steam at high temperature and 
moderate pressure. In this way, the chemical reaction taking place leads to hydrogen and carbon dioxide (Reaction 1):

$$
\mathrm{CH}_{3} \mathrm{CH}_{2} \mathrm{OH}+\mathrm{H}_{2} \mathrm{O} \rightarrow 2 \mathrm{CO}_{2}+6 \mathrm{H}_{2} \quad \Delta \mathrm{H}_{\mathrm{r}}=174 \mathrm{~kJ} \mathrm{~mol}^{-1}
$$

However, depending on the reaction mixture and operating conditions in the reactor, another route can be followed, producing undesirable products ( $\mathrm{Ni}$ et al., 2007), such as carbon monoxide (Reaction 2), methane (Reaction 3) or ethylene (Reaction 4):

$$
\mathrm{CH}_{3} \mathrm{CH}_{2} \mathrm{OH}+\mathrm{H}_{2} \mathrm{O} \rightarrow 2 \mathrm{CO}+4 \mathrm{H}_{2} \quad \Delta \mathrm{H}_{\mathrm{r}}=256 \mathrm{~kJ} \mathrm{~mol}^{-1}
$$

$$
\mathrm{CH}_{3} \mathrm{CH}_{2} \mathrm{OH} \rightarrow \mathrm{CO}+\mathrm{CH}_{4}+\mathrm{H}_{2} \quad \Delta \mathrm{H}_{\mathrm{r}}=50 \mathrm{~kJ} \mathrm{~mol}^{-1}
$$

$$
\mathrm{CH}_{3} \mathrm{CH}_{2} \mathrm{OH} \rightarrow \mathrm{C}_{2} \mathrm{H}_{4}+\mathrm{H}_{2} \mathrm{O} \quad \Delta \mathrm{H}_{\mathrm{r}}=46 \mathrm{~kJ} \mathrm{~mol}^{-1}
$$

Once the process is complete, the output stream must undergo purification treatment to avoid the presence of by-products such as methane and carbon monoxide. The removal of $\mathrm{CO}$ is an important step because it normally poisons the catalyst in fuel cells, that is why CO is removed first by the Water Gas Shift (WGS) reaction (Reaction 5). WGS is an exothermic and reversible reaction usually used in industry to produce high purity hydrogen (Alamolhoda et al., 2019). Normally, $90 \%$ of the CO outflowing from the steam reforming reactor can be converted to $\mathrm{CO}_{2}$ (Rossetti et al., 2015b).

$\mathrm{CO}+\mathrm{H}_{2} \mathrm{O} \rightarrow \mathrm{H}_{2}+\mathrm{CO}_{2}$

$$
\Delta \mathrm{H}_{\mathrm{r}}=-41 \mathrm{~kJ} \mathrm{~mol}^{-1}
$$

Following this stage, the Pressure Swing Adsorption (PSA) process separates hydrogen from the rest of the components of the gas stream with $85 \%$ efficiency, obtaining $\mathrm{H}_{2}$ with $99 \%$ purity (Susmozas et al., 2013), and whose energy content is usually higher than that of the natural gas used for reforming.

The implementation of other alternatives of hydrogen production can be considered from alternative raw materials, such as alcohols (Rossetti et al., 2015a). In addition to steam reforming of ethanol, studies have been published on steam reforming of different types of 
110 alcohol with the aim of producing hydrogen. Some of these alcohols are butanol (Kumar et al.,

111 2018), propanol (Wang et al., 2015), methanol (Tian et al., 2017) or glycerol (Menezes et al.,

112 2018) but, even so, the use of ethanol for this purpose offers the best opportunity to produce

113 hydrogen from renewable sources (Ramírez and Homs, 2008), especially if this ethanol is

114 derived as residue from other processes. Specifically, the alcoholic wastes from the wine

115 industry results an attractive raw material due to $65 \%$ of world wine production is managed by

116 European winegrowers mostly small and medium-sized wineries according to the Comité

117 Européen des Enterprises Vins (CEEV, 2016). Wine production generates large amounts of solid

118 and liquid wastes, with a serious impact on the environment when they are not adequately

119 treated. The liquid wastes are processed in distilleries to obtain purified alcohols, but in these

120 processes, alcoholic purges without commercial value containing impurities separated from

121 the good quality alcohols are generated. Thus, the process here analysed aims to raise

122 awareness of the potential of these by-products and their valorization activities as a

123 sustainable way to produce hydrogen.

124 The main objective of the study is to analyze the potential environmental impacts associated

125 with the steam reforming of alcoholic waste from distilleries. Quantifying the consumption of

126 material and energy resources during the life cycle makes it possible to estimate potential

127 changes and emissions to the environment. The main product of the process is hydrogen $\left(\mathrm{H}_{2}\right)$,

128 along with a certain amount of carbon monoxide $(\mathrm{CO})$, carbon dioxide $\left(\mathrm{CO}_{2}\right)$, methane $\left(\mathrm{CH}_{4}\right)$

129 and ethylene $\left(\mathrm{C}_{2} \mathrm{H}_{4}\right)$, which accounts for a proportion lower than $30 \%$. This output stream is

130 used to produce energy in a $3 \mathrm{~kW}$ SOFC.

\section{Materials and methods}

\subsection{Definition of goal and scope}

The Life Cycle Analysis methodology has been considered as a fundamental tool in the analysis 
distilleries in order to identify key environmental performance indicators. In distilleries, alcohol can be extracted from some wines that cannot been marketed. During this distillation process, an ethanol-rich fraction is obtained, but also a residual fraction that remains in the distiller's tail, which is the residue used in this study.

Figure 1 presents the block diagram of the process, identifying the system boundaries, the different subsystems considered and the main inputs and outputs of the system.

No infrastructure process was considered in the evaluation, since the environmental impacts per process unit, from installation, construction, decommissioning, infrastructure, machinery, etc., have been considered negligible during the lifetime of this type of facilities. This has been large installations.

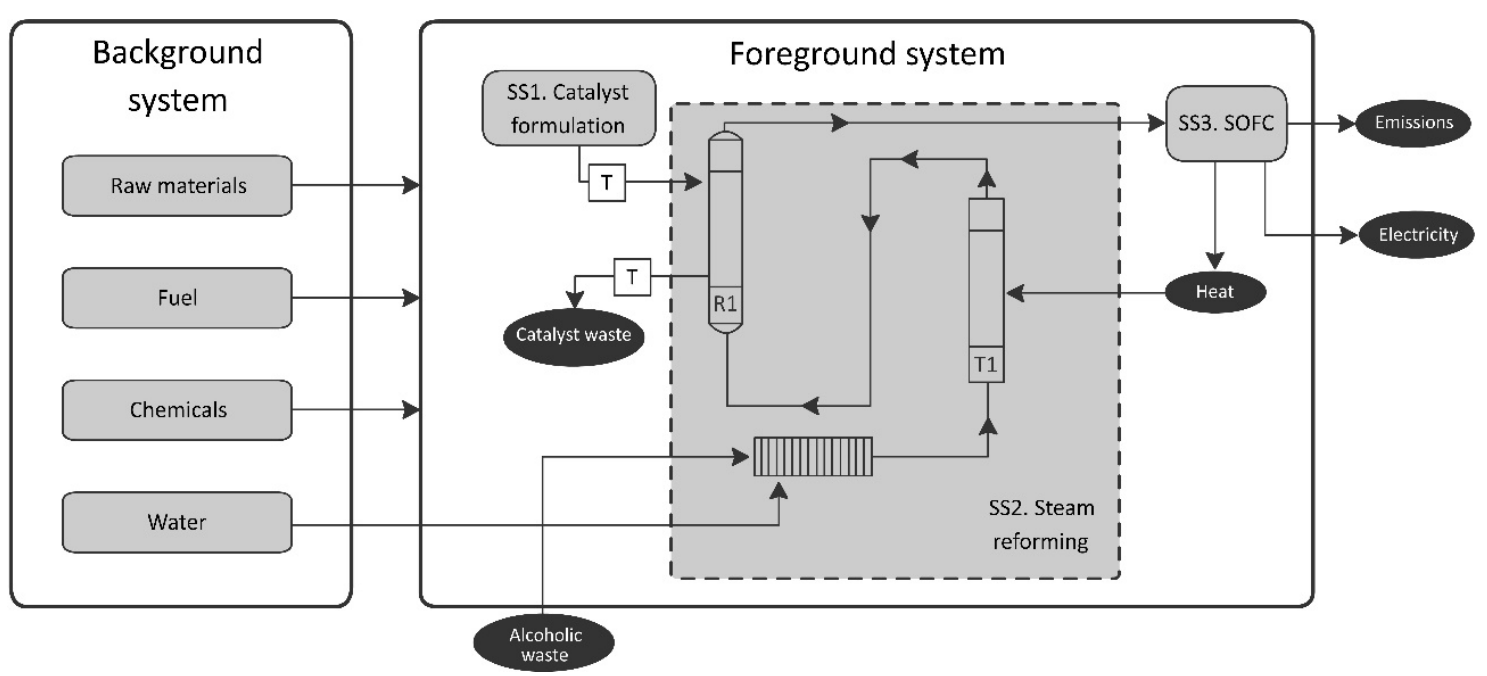

Figure 1. System boundaries of the reforming system for the valorization of the alcoholic waste. Caption: T: Transport; R1: Reforming reactor; T1: Heat exchanger. 
151 The foreground system includes the process units that are the direct object of this study. For

152 the purposes of the study, three subsystems (SS) have been considered, which are detailed

153 below:

Subsystem 1: Catalyst formulation. This subsystem considers all the materials necessary for the manufacture of the catalyst used in the reforming reactor (Menor et al., 2017). The catalyst is composed of a sepiolite base with Nickel ( $15 \%$ weight) and Lanthanum ( $1 \%$ weight). Its considered useful life is 20 months, regenerating every 4 months. The transport of the catalyst to the plant is also considered, taking as distance $100 \mathrm{~km}$.

Subsystem 2: Steam reforming. This process includes all the inputs needed to perform the steam reforming process. These inputs are mainly electricity, water and alcohol residues from distilleries. The transport of alcoholic waste to the plant is not included, as this type of facility is designed to be included in the distillery. The waste produced in this subsystem is the catalyst spent at the end of its useful life and is considered $100 \mathrm{~km}$ as the average transport to the landfill.

Subsystem 3: SOFC. This subsystem includes the net production of electricity in the SOFC using the SS2 gas stream as feed. At the exit of this subsystem, $\mathrm{CO}_{2}$ and $\mathrm{H}_{2} \mathrm{O}$ emissions are derived from the reactions taking place with $\mathrm{CO}$ and $\mathrm{CH}_{4}, \mathrm{C}_{2} \mathrm{H}_{4}$ and $\mathrm{H}_{2}$ inside the SOFC. The electricity produced is fed into the grid. The SOFC works at a high temperature of around $600^{\circ} \mathrm{C}$ and produces a large amount of heat, as represented is Figures 1 and 2, this heat is redirected to the system and used to heat the stream entering the reforming reactor. This subsystem includes the SOFC manufacturing stage. Gas stream purifying processes are not included because SOFC are not poisoned by the presence of CO (Hernández and Kafarov, 2009). This type of device directly provides electricity from the chemical reaction taking place. The electrodes of this type of battery are catalytic, so they are relatively stable and are not consumed (Fragiacomo et al., 2018). 
176 The Background System includes the production of raw materials, fuel, chemicals and water

177 used in the process, as well as the consumption of fuel used in the transportation of materials.

178 As the basis for the calculation or Functional Unit (FU), the treatment of 1 tonne of alcoholic

179 waste in the facility was chosen, which will be taken as a reference for all the inputs and

180 products of the system as well as the emissions, energy consumption and transport associated

181 with this process (ISO, 2006a, 2006b).

182 The description of the steam reforming process is presented in detail in Figure 2 . The waste

183 from the distillery enters the plant with approximately $92 \% \mathrm{v} / \mathrm{v}$ ethanol, to which water is

184 added to reach $80 \% \mathrm{v} / \mathrm{v}$ water and $20 \% \mathrm{v} /$ ethanol. The steam-to-carbon molar ratio ( $\mathrm{S} / \mathrm{C}$ ratio)

185 used in most cases is 3:1 (Jeon et al., 2018), but in this case a steam-to-carbon ratio of 6:1 was

186 considered. This steam-to-carbon ratio increases the production of $\mathrm{CO}_{2}$ and $\mathrm{H}_{2}$ and reduces the

187 formation of the undesirable products mentioned in Equations 2-4, but increases the heat

188 necessary to vaporize the water/ethanol mixture. However, since this heat is supplied by the

189 residual heat produced in the SOFC, the use of additional fuel is not necessary. The stream

190 passes through a heat exchanger where it is heated up to $600^{\circ} \mathrm{C}$, the temperature required for

191 the inlet stream of the reforming reactor. The output of the reactor is a gas stream comprised

192 by $\mathrm{H}_{2}, \mathrm{CO}_{2}, \mathrm{CO}, \mathrm{CH}_{4}, \mathrm{H}_{2} \mathrm{O}$ and a minor proportion of $\mathrm{C}_{2} \mathrm{H}_{4}$. This stream is fed to the SOCF, where

193 heat and electricity are produced. The high temperature stream is recycled in the system to

194 heat the water and ethanol feed, reducing energy consumption. The electricity produced is fed

195 into the grid. 


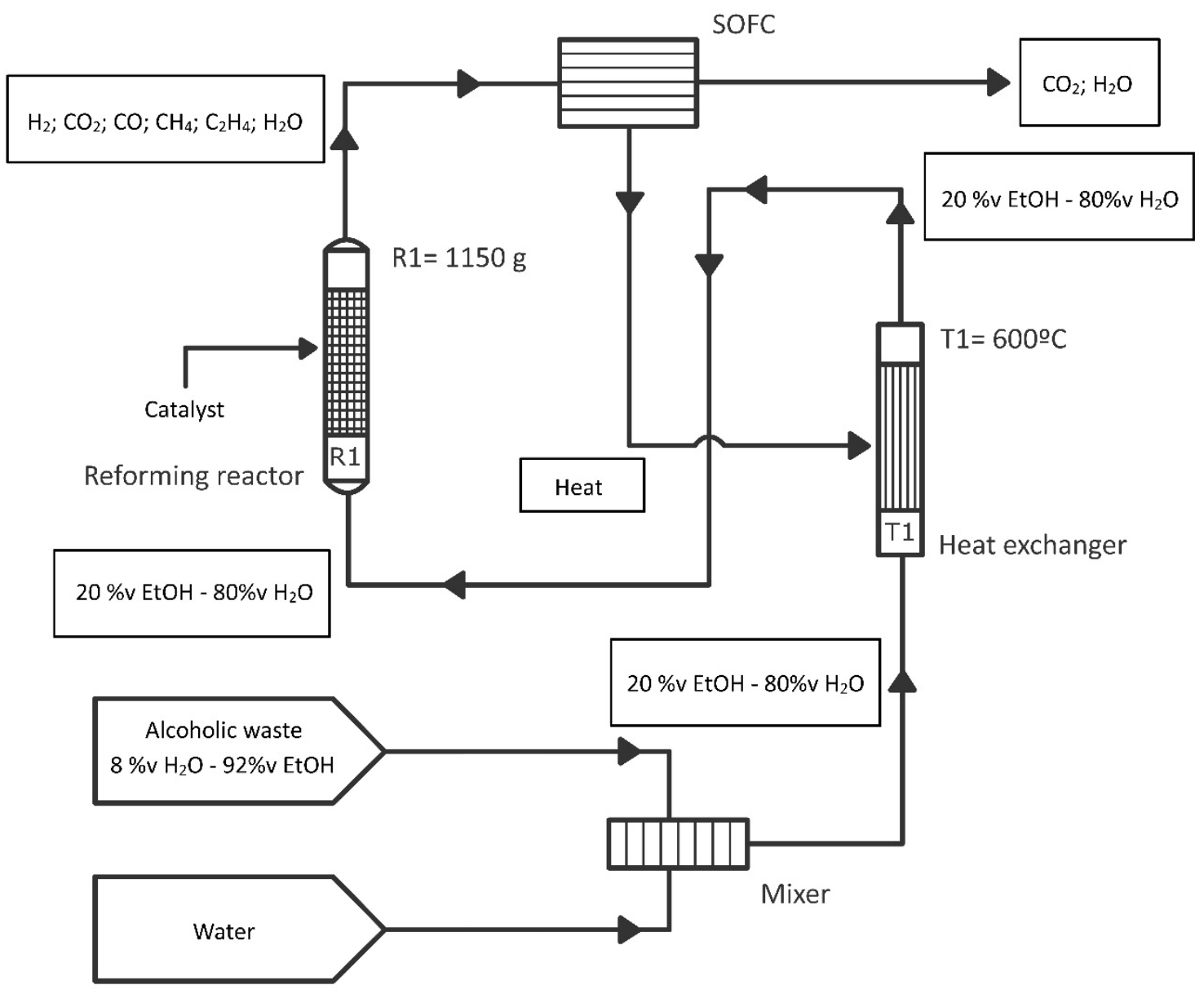

Figure 2. Detailed scheme of Subsystem 2, showing the composition of the different streams and their temperature.

\subsection{Data acquisition and life cycle inventory}

Life cycle inventory involves the collection of qualitative and/or quantitative input/output data for the system. In the case of Subsystem 1, catalyst manufacturing data were obtained from a previous study about the formulation of a sepiolite-based catalyst with the addition of $\mathrm{Ni}$ (Menor et al., 2017), although the amount of catalyst used is a primary data. In relation to the Steam Reforming Subsystem, all the information on the consumption of the process comes from primary data, except electricity consumption, which was obtained from a study about the life-cycle assessment of biomass gasification as an alternative to steam methane reforming for hydrogen production (Susmozas et al., 2013); where an electric consumption of $1.35 \mathrm{kWh}$ per $\mathrm{kg} \mathrm{H}_{2}$ produced was considered. Finally, the inventory of Subsystem 3 has been obtained from 
various scientific publications. (Strazza et al., 2015, 2010) conducted several studies to assess

210 the environmental profile of two SOFC systems: one with $230 \mathrm{~kW}$ and other one with $20 \mathrm{~kW}$

211 system. (Lee et al., 2015) obtained the environmental impact of a $100 \mathrm{~kW}$ SOFC power

212 generation system. The different life cycle inventories published in the above-mentioned

213 manuscripts were adapted to the characteristics of the battery used in the study. Background

214 system processes have been taken from Ecoinvent ${ }^{\circledR}$ database. Tables 1-3 present the life cycle

215 inventory of the different subsystem considered in this study.

216 Table 1. Life cycle inventory for Subsystem 1. Catalyst formulation per FU

\begin{tabular}{lclc}
\hline \multicolumn{2}{c}{ Inputs from Technosphere } & \multicolumn{2}{c}{ Outputs to Technosphere } \\
\hline Materials & $\mathbf{k g}$ & Products & $\mathbf{k g}$ \\
MiliQ water & 2.63 & Catalyst to SS2 & $8.15 \cdot 10^{-2}$ \\
$\mathrm{Ni}\left(\mathrm{NO}_{3}\right)_{2} \cdot 6 \mathrm{H}_{2} \mathrm{O}$ & $6.05 \cdot 10^{-2}$ & Wastes & $\mathbf{1}$ \\
$\mathrm{La}\left(\mathrm{NO}_{3}\right)_{3} \cdot 6 \mathrm{H}_{2} \mathrm{O}$ & $2.54 \cdot 10^{-3}$ & Wastewater & 2.63 \\
Sepiolite & $6.84 \cdot 10^{-2}$ & & \\
Energy & $\mathbf{k W h}$ & & \\
Electricity & 0.72 & & \\
Transport & $\mathbf{k g} \cdot \mathbf{k m}$ & & \\
Catalyst to plant & 8.15 & & \\
\hline
\end{tabular}

217

218 Table 2. Inventory for subsystem S2. Steam Reforming per FU

\begin{tabular}{lccc}
\hline \multicolumn{4}{c}{ Inputs from Technosphere } \\
\hline Materials & $\mathbf{k g}$ & Energy & MWh \\
Water & 4470 & Electricity & $2.49 \cdot 10-1$ \\
Alcoholic waste & 1000 & Transport & $\mathbf{k g} \cdot \mathbf{k m}$ \\
Catalyst from SS1 & $8.15 \cdot 10^{-2}$ & Catalyst waste to landfill & 8.15 \\
\hline \multicolumn{4}{c}{ Outputs to Technosphere } \\
\hline Products & $\mathbf{k g}$ & Waste & $\mathbf{k g}$ \\
Gas stream to SS3 & 5509 & Catalyst waste to landfill & $8.15 \cdot 10^{-2}$ \\
\hline
\end{tabular}

219 
Table 3. Life cycle inventory for Subsystem SS3. SOFC per FU

\begin{tabular}{lclc}
\hline \multicolumn{4}{c}{ Inputs from Technosphere } \\
\hline Materials & $\mathbf{k g}$ & Materials & $\mathbf{k g}$ \\
$\mathrm{LaMnO}_{3}$ & 10.05 & Polyethyleneglycol & 0.03 \\
$\mathrm{LaCrO}_{3}$ & 0.15 & Dibutylpthalat & 0.03 \\
Zirconium chloride & 1.96 & Water, deionised & 2.32 \\
Yttrium chloride & 0.29 & Nitric acid & 13.45 \\
Zirconium oxide & 0.18 & Chlorine & 1.61 \\
Nickel oxide & 0.18 & Petroleum coke & 0.26 \\
Nickel & $2.36 \cdot 10^{-4}$ & Urea, as N & 6.61 \\
Ethanol & 0.44 & Gas stream from SS2 & 5509 \\
Polyvinilbutyral & 0.07 & Transport & $\mathbf{k g} \cdot \mathbf{k m}$ \\
Energy & $\mathbf{M J}$ & Freight rail & 31.92 \\
Heating, natural gas & 50.76 & Lorry > 16t & 5.67 \\
Spray drying, natural gas & 560.71 & Transoceanic freight & 202.09 \\
\hline \multicolumn{1}{c}{ Outputs to Technosphere } & & Outputs to Nature \\
\hline Products & $\mathbf{M W h}$ & Emissions & $\mathbf{k g}$ \\
Electricity & $1.81 \cdot 10^{-1}$ & CO & \\
& & $\mathrm{CO}_{2}$, biogenic & 1800 \\
& & $\mathrm{H}_{2} \mathrm{O}$ & 33.10 \\
\hline
\end{tabular}

223

Simapro 8.5.2 (PRé Consultants, 2017) has been the software used for the implementation of

the Life Cycle Inventory. To analyze the inputs and outputs of the Life Cycle Inventory, the

227 Classification and Characterization guidelines defined by ISO 14040 and ISO 14044 (ISO, 2006a,

228 2006b) were followed. The environmental results have been presented in terms of the following impact categories of the ReCiPe methodology: Climate Change (CC), Ozone Layer Depletion (OD), Terrestrial Acidification (TA), Freshwater Eutrophication (FE), Marine 
237 The environmental characterization of the alcoholic waste steam reforming resulted in the

238 impacts reported in Table 4. All impacts in Table 4 are attributed to the Functional Unit (1

239 tonne feedstock).

240 Table 4. Characterized results of the system per FU

\begin{tabular}{llcccc}
\hline Impact category & Units & SS1 & SS2 & SS3 & Total \\
\hline CC & kg CO 2 eq & 33.08 & 109.91 & 207.79 & 350.78 \\
OD & kg CFC-11 eq & $5.98 \cdot 10^{-6}$ & $1.40 \cdot 10^{-5}$ & $4.52 \cdot 10^{-5}$ & $6.52 \cdot 10^{-5}$ \\
TA & kg SO eq & 0.22 & 0.67 & 1.32 & 2.21 \\
FE & kg P eq & $1.41 \cdot 10^{-2}$ & $3.09 \cdot 10^{-2}$ & $7.56 \cdot 10^{-2}$ & $1.21 \cdot 10^{-1}$ \\
ME & kg N eq & $6.08 \cdot 10^{-2}$ & $2.16 \cdot 10^{-2}$ & $4.23 \cdot 10^{-2}$ & $1.25 \cdot 10^{-1}$ \\
HT & kg 1,4-DB eq & 17.11 & 24.57 & 122.23 & 163.91 \\
POF & kg NMVOC & 0.10 & 0.35 & 0.62 & 1.07 \\
PMF & kg PM10 eq & 0.10 & 0.24 & 0.66 & 1.00 \\
TET & kg 1,4-DB eq & $1.04 \cdot 10^{-2}$ & $3.15 \cdot 10^{-3}$ & $8.05 \cdot 10^{-2}$ & $9.41 \cdot 10^{-2}$ \\
FET & kg 1,4-DB eq & 0.76 & 1.59 & 4.67 & 7.01 \\
MET & kg 1,4-DB eq & 0.61 & 1.42 & 3.68 & 5.71 \\
FD & kg oil eq & 11.65 & 30.11 & 89.78 & 131.55 \\
\hline
\end{tabular}

241

242 The SOFC is the main contributor to the Climate Change (CC) category, since this subsystem

243 comprises several processes necessary for the manufacture of the main components. In SS3,

244 direct emissions into the atmosphere are quantified, directly from the alcoholic stream,

245 residue produced from grape fermentation. Therefore, $\mathrm{CO}_{2}$ emissions from SS3 should not be

246 considered as fossil carbon, but as biogenic $\mathrm{CO}_{2}$. This decision agrees with a study on the

247 production of hydrogen and electricity by reforming supercritical water from bioglycerol

248 feedstock (Galera and Gutiérrez-Ortiz, 2015). If $\mathrm{CO}_{2}$ was not considered biogenic, direct $\mathrm{CO}_{2}$

249 emissions would represent almost $60 \%$ of environmental impact in the climate change

250 category. Therefore, the final impact on this category would be $2146 \mathrm{~kg} \mathrm{CO}_{2}$ eq per tonne of

251 alcoholic waste processed at the facility. 
252 The Ozone Layer Depletion category has fairly low values in all subsystems. Freshwater and

253 Marine Eutrophication (FE and ME) show similar behavior, as they are influenced by the same

254 type of substances. The impact value in these categories is relatively similar in all subsystems,

255 which makes the final impact value low. Human Toxicity (HT) and Fossil Depletion (FD) have

256 relatively high levels compared to the rest of the impact categories. The reason is the

257 formulation of catalysts and the manufacture of SOFC, since heavy metals and hazardous

258 substances are required that cause a high impact in the HT category. As for the FD category, its

259 value is related to the high consumption of fossil fuels associated with the formulation of

260 catalysts and the manufacture of SOFC.

261 The specific contribution of each subsystem to the impacts calculated for the system is shown

262 in Figure 3. The manufacture and operation of the SOFC (SS3) was found to dominate almost

263 all impact categories, with percentages ranging from $57.7 \%$ in Photochemical Oxidant

264 Formation (POF) to $85.6 \%$ in Terrestrial Ecotoxicity (TET). Additionally, the steam reforming

265 subsystem (SS2) showed a significant contribution to Climate Change (31,3\%), Terrestrial

266 Acidification (30,4\%) and Photochemical Oxidant Formation (32,9\%). The remaining subsystem

267 (SS1) accounted for a contribution percentage around 10\%, except for ME, where the contribution was higher than $45 \%$. 


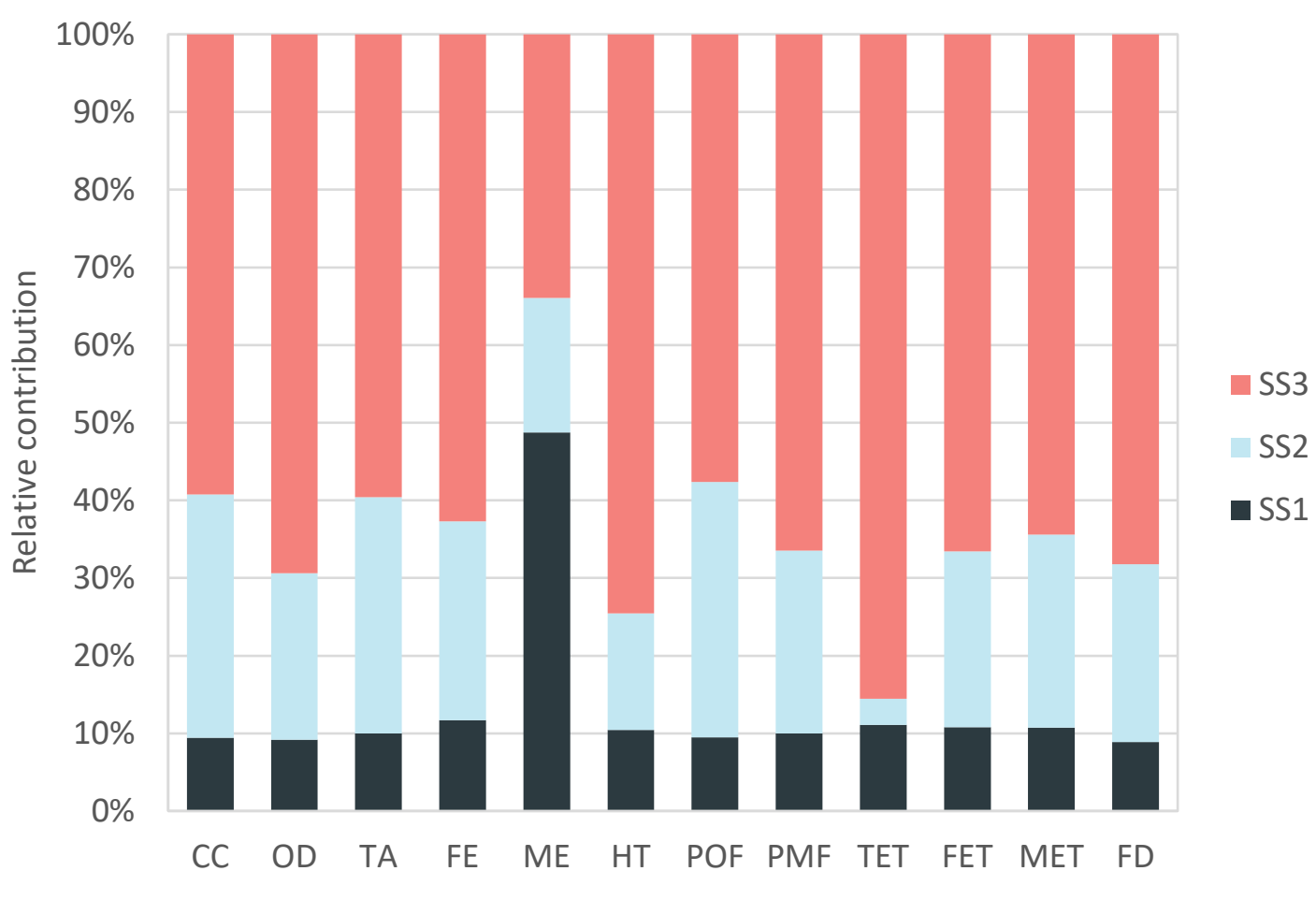

270 Figure 3. Relative contribution (\%) of the different subsystems to the total environmental

271 impact

272 In order to highlight the processes with the highest environmental impact on the life cycle

273 performance of the system, the individual contributions to the impact are broken down in

274 Figure 4. These results show that SOFC manufacturing is the major contribution in almost all impact categories, except for ME. Therefore, the manufacture of SOFC is the main hotspot of the system and must have the highest priority in the improvement actions from the environmental point of view.

The second largest contributor to the total environmental impact is electricity consumption, with contributions percentage ranging from $15 \%$ in $\mathrm{HT}$ to $32.9 \%$ in POF. If electricity production is taken into account, its contribution to environmental impact decreases significantly to $4.2 \%$ and $9.1 \%$ in $\mathrm{HT}$ and POF, respectively. The formulation of catalysts presented a uniform distribution of environmental impacts in all categories, with contributions always below $10.6 \%$. The consumption of natural gas to heat the process is only responsible for a maximum of $9.4 \%$ in $\mathrm{CC}$ and $8.5 \%$ in FD, but in the rest of the impact categories, their 
contributions never exceed $6 \%$. The rest of the substances (transport, water consumption and waste treatment) contributed practically insignificantly to the environmental impact.

Wastewater treatment is the main contributor to the ME impact, due to the high amount of nitrogen-based compounds such as nitrites and nitrates that are discharged in the treated effluent. This may explain, as seen in Figure 3, why the main contributor to the ME impact category is SS1, due to the wastewater generated during the formulation of the catalyst.
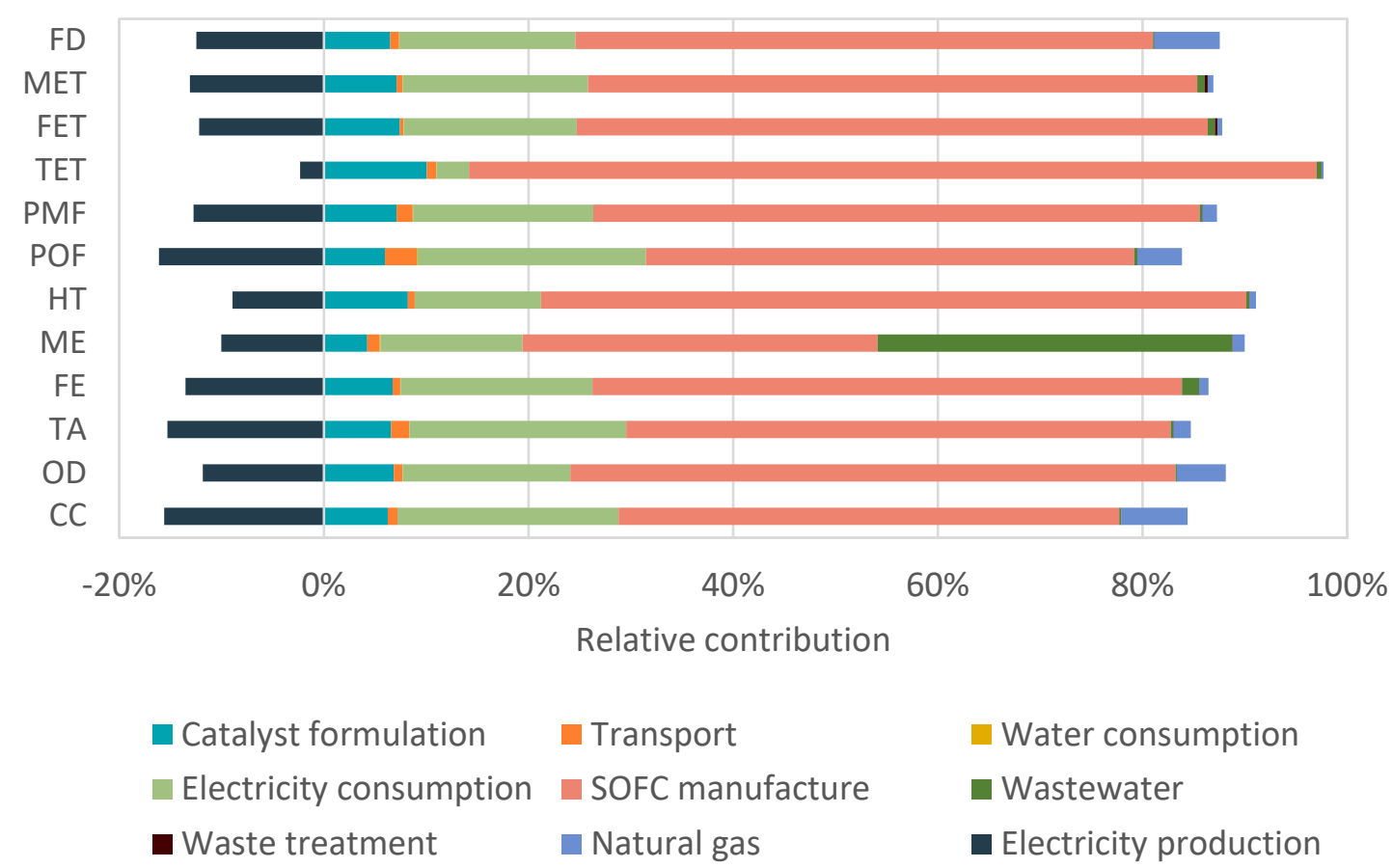

291

292 Figure 4. Relative contribution (\%) of the components of alcoholic waste steam reforming to the overall impact The environmental profile of alcoholic waste steam reforming is mainly due to two factors. On the one hand, the use of a raw material that is considered waste from another process and therefore has no associated environmental impact. On the other hand, the production of electricity makes it possible to obtain environmental credits that promote a better environmental profile. 
301 In order to compare the environmental characterization results of some alternative waste

302 treatments to steam reforming, a sensitivity analysis was performed. The methods selected for

303 this analysis were landfill and incineration. Note that the inventory data for incineration and

304 landfill were taken from the Ecoinvent ${ }^{\circledR}$ database. Figure 5 depicts the environmental

305 performance of the alternative treatments for the alcoholic waste considered. As noted, the

306 steam reforming scenario potentially implied a more acceptable environmental profile than

307 the other scenarios, except for Ozone Layer Depletion, Terrestrial Acidification, Freshwater

308 Eutrophication and Terrestrial Ecotoxicity. In particular, steam reforming makes it possible to

309 reduce GHG emissions by $33 \%$ compared to incineration and by $30 \%$ compared to landfill.

310 Steam reforming is the largest contributor to OD impact for the emission of harmful gases to

311 the stratospheric ozone layer during some operations such as electricity generation or

312 chemical production. Regarding Terrestrial Acidification and Freshwater Eutrophication, steam

313 reforming presents the worst environmental performance. The consumption of Ni-based

314 compounds in the manufacture of SOFC and some processes derived from the extraction of

315 lanthanum for SOFC are the responsible processes of the poor performance in TA and FE

316 respectively. With respect to TET, steam reforming has worse results, but if the three

317 ecotoxicity categories (TTE, MET and FET) are considered, the environmental impact of steam

318 reforming is lower, improving $95.8 \%$ with respect to incineration and $97.8 \%$ with respect to the

319 sanitary landfill. 


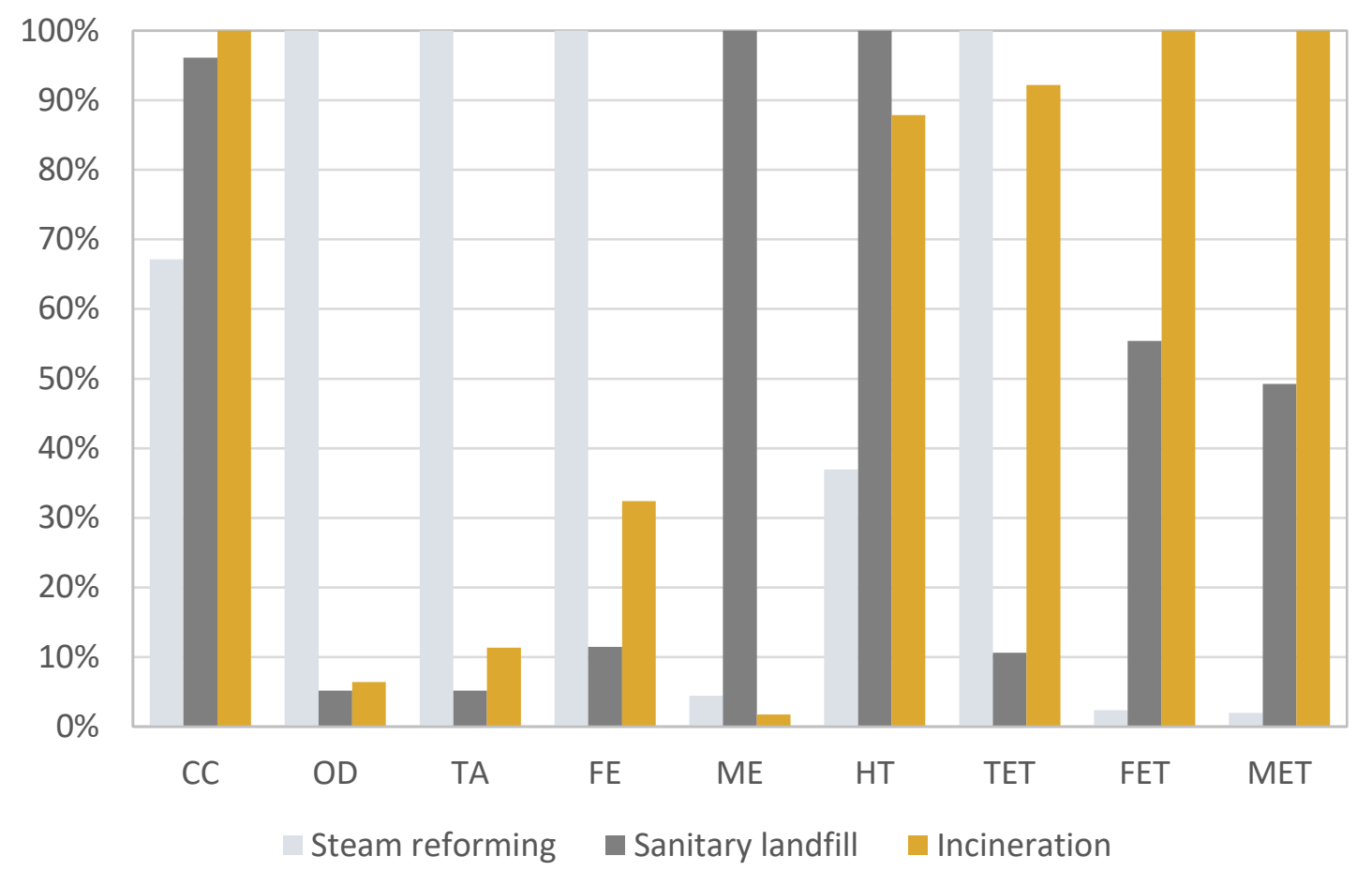

321 Figure 5. Comparative environmental profile of the alternative treatments for alcoholic waste

322 considering 1 tonne as functional unit

3.3. Comparative analysis

In addition to the basic scheme, a comparison was made with some processes published in the scientific literature. The FU was changed to $1 \mathrm{~kg}$ of hydrogen produced in the plant with 99.9 vol\% purity by steam reforming (Figure 6), in agreement with other reforming studies using other raw materials for hydrogen production (Hajjaji et al., 2016, 2013; Khila et al., 2016; Susmozas et al., 2016, 2015, 2013), thus allowing the comparison of the environmental profile of different processes. Therefore, the new facility configuration does not consider the operation of the SOFC, consequently the output stream of the system is led to a purification system: First, the WGS process removes carbon monoxide and produces a small amount of additional hydrogen. Additionally, in a COPROX reactor the remaining $\mathrm{CO}$ can be further reduced to $\mathrm{CO}_{2}$ in the presence of oxygen. Finally, the PSA process separates $\mathrm{H}_{2}$ from the rest of the gases in the stream, obtaining $\mathrm{H} 2$ with $99 \%$ purity. Therefore, two additional subsystems were introduced to purify the output hydrogen stream (SS3) and provide cooling water (SS4) 


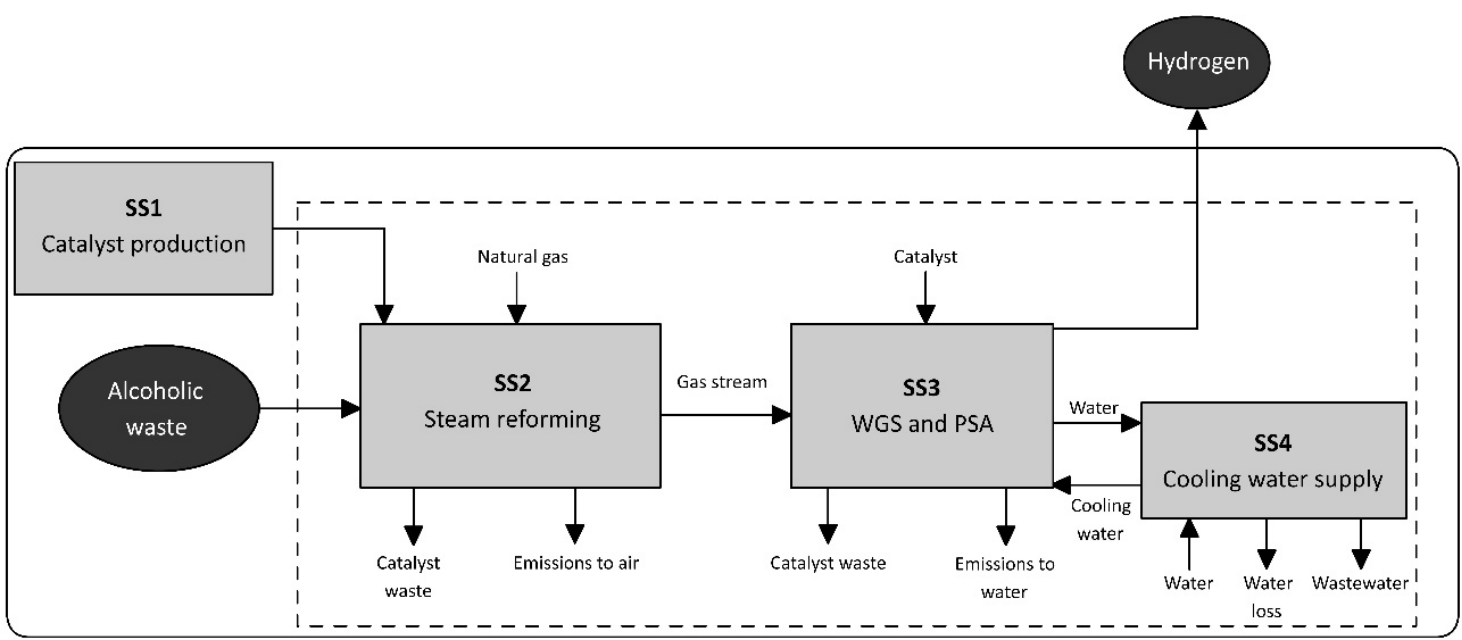

Figure 6. New flowchart considered to compare the steam reforming of alcoholic waste with other published studies.

The following processes have been considered: SMR- $\mathrm{H}_{2}$ : Steam reforming of methane obtained from natural gas (Susmozas et al., 2013). PG-H 2 : Poplar biomass gasification. The system includes the cultivation of poplar and its transport to the plant. Once in the plant are included all the operations necessary to obtain hydrogen and the production of electricity from the steam produced in the system (Susmozas et al., 2013). PG\&C- $\mathrm{H}_{2}$ : Gasification of poplar biomass, as mentioned above, but includes carbon fixation during the cultivation stage (Susmozas et al., 2016). GSR-H ${ }_{2}$ : Glycerol reforming, obtained as a co-product of biodiesel production by transesterification of rapeseed oil. Carbon sequestration during oil production is considered (Susmozas et al., 2015). BSR- $\mathrm{H}_{2}$ : Biofuel reforming, including also carbon fixation produced during the growth of biomass used for biofuel (Susmozas et al., 2015). SBR- $\mathrm{H}_{2}$ : Steam reforming of bioethanol, including bioethanol production (Hajjaji et al., 2016). BAR- $\mathrm{H}_{2}$ : Autothermal reforming of bioethanol (Khila et al., 2016). In order to carry out the comparative analysis, life cycle inventories were modified. In relation to the type and quantity of reaction catalyst, the WGS data were obtained from (Compagnoni et al., 2017). All the necessary data to measure the inputs and outputs in SS3. WGS and PSA 
and SS4. Cooling water supply were obtained from (Susmozas et al., 2015, 2013). Inventory data of WGS, PSA and Cooling water supply can be found in Table 5.

Table 5. New life cycle inventory to compare the steam reforming of alcoholic wastes with other published processes

\begin{tabular}{lccc}
\hline \multicolumn{2}{c}{ Inputs from Technosphere } & \multicolumn{2}{c}{ Outputs to Technosphere } \\
\hline Materials & $\mathbf{k g}$ & Products & $\mathbf{k g}$ \\
Alcoholic waste & 5.42 & $\mathrm{H}_{2}$ & 1.00 \\
Water & 24.21 & Emissions & $\mathbf{~ k g}$ \\
SR catalyst & $4.41 \cdot 10^{-4}$ & $\mathrm{CO}_{2}$ & 8.16 \\
WGS catalyst & $1.11 \cdot 10^{-3}$ & $\mathrm{CH}_{4}$ & 0.45 \\
Energy & $\mathbf{k W h}$ & $\mathrm{C}_{2} \mathrm{H}_{4}$ & $9.41 \cdot 10^{-3}$ \\
Electricity & 1.36 & $\mathrm{CO}$ & 1.97 \\
Transport & $\mathbf{t} \cdot \mathbf{k m}$ & Wastes & $\mathbf{k g}$ \\
Road & 0.48 & SR catalyst to landfill & $1.11 \cdot 10^{-3}$ \\
& & WGS catalyst to landfill & $4.41 \cdot 10^{-4}$ \\
& & Wastewater from WGS & 4.61 \\
\hline
\end{tabular}

358

The results of the comparison between steam reforming of alcoholic residues and other related processes are presented in terms of the impact categories of the CML methodology Global warming potential (GWP - kg CO $\mathrm{CO}_{2}$ eq), Depletion of abiotic resources ( $\mathrm{ADP}-\mathrm{kg} \mathrm{Sb}$ eq), Ozone layer depletion (ODP - kg CFC-11 eq), Photochemical oxidation (POFP - $\mathrm{kg} \mathrm{C}_{2} \mathrm{H}_{4} \mathrm{eq}$ ), Acidification potential ( $\mathrm{AP}-\mathrm{kg} \mathrm{SO}_{2}$ eq) and Eutrophication potential $\left(\mathrm{EP}-\mathrm{kg} \mathrm{PO}_{4}{ }^{3-}\right)$. The magnitudes of the environmental impacts of hydrogen production systems are displayed in Table 6, in order to simplify the comparative study, the results are scaled to 100 and represented in Figure 7. For example, alcoholic waste steam reforming shows the best results in terms of $A D P, O D P, A P$ and $E P$, but performs worse in GWP and has the worst result in POFC. 
Table 5. Summarized results of comparative life cycle assessment

\begin{tabular}{|c|c|c|c|c|c|c|c|}
\hline Processes & GWP & ADP & ODP & POFP & AP & EP & Reference \\
\hline $\begin{array}{l}\text { Present } \\
\text { study }\end{array}$ & 9.55 & 3 & 8 & 3 & -3 & 4 & udy \\
\hline $\mathrm{SMR}-\mathrm{H}_{2}$ & 10.60 & 0.90 .10 & $1.20 \cdot 10$ & 3.10 .10 & 0.40 .10 & $1.64 \cdot 10^{-3}$ & (Susmozas et al., 2013) \\
\hline PG- $\mathrm{H}_{2}$ & 0.41 & $8.57 \cdot 10^{-2}$ & $1.62 \cdot 10^{-7}$ & $4.40 \cdot 10^{-4}$ & $1.19 \cdot 10^{-2}$ & $2.85 \cdot 10^{-3}$ & (Susmozas et al., 2013) \\
\hline$P G \& C-H_{2}$ & -14.60 & --- & $2.85 \cdot 10^{-7}$ & $8.31 \cdot 10^{-4}$ & $2.07 \cdot 10^{-2}$ & $4.60 \cdot 10^{-3}$ & (Susmozas et al., 2016) \\
\hline GSR-H ${ }_{2}$ & 12.70 & $5.69 \cdot 10^{-2}$ & $8.90 \cdot 10^{-7}$ & $5.16 \cdot 10^{-4}$ & $6.51 \cdot 10^{-2}$ & $5.26 \cdot 10^{-2}$ & (Susmozas et \\
\hline $\mathrm{BSR}-\mathrm{H}_{2}$ & 3.79 & $4.13 \cdot 10^{-2}$ & $5.54 \cdot 10^{-7}$ & $6.00 \cdot 10^{-4}$ & $1.56 \cdot 10^{-2}$ & $3.20 \cdot 10^{-3}$ & 015) \\
\hline $\mathrm{SBR}-\mathrm{H}_{2}$ & 6.81 & $2.13 \cdot 10^{-2}$ & $3.96 \cdot 10^{-7}$ & $1.55 \cdot 10^{-3}$ & $3.53 \cdot 10^{-2}$ & $2.54 \cdot 10^{-2}$ & $., 2016)$ \\
\hline BAR- ${ }_{2}$ & 7.27 & $4.87 \cdot 10^{-2}$ & $3.13 \cdot 10^{-6}$ & $1.65 \cdot 10^{-3}$ & $2.76 \cdot 10^{-2}$ & $2.81 \cdot 10^{-2}$ & (Khila et al., 2016) \\
\hline
\end{tabular}

372

373

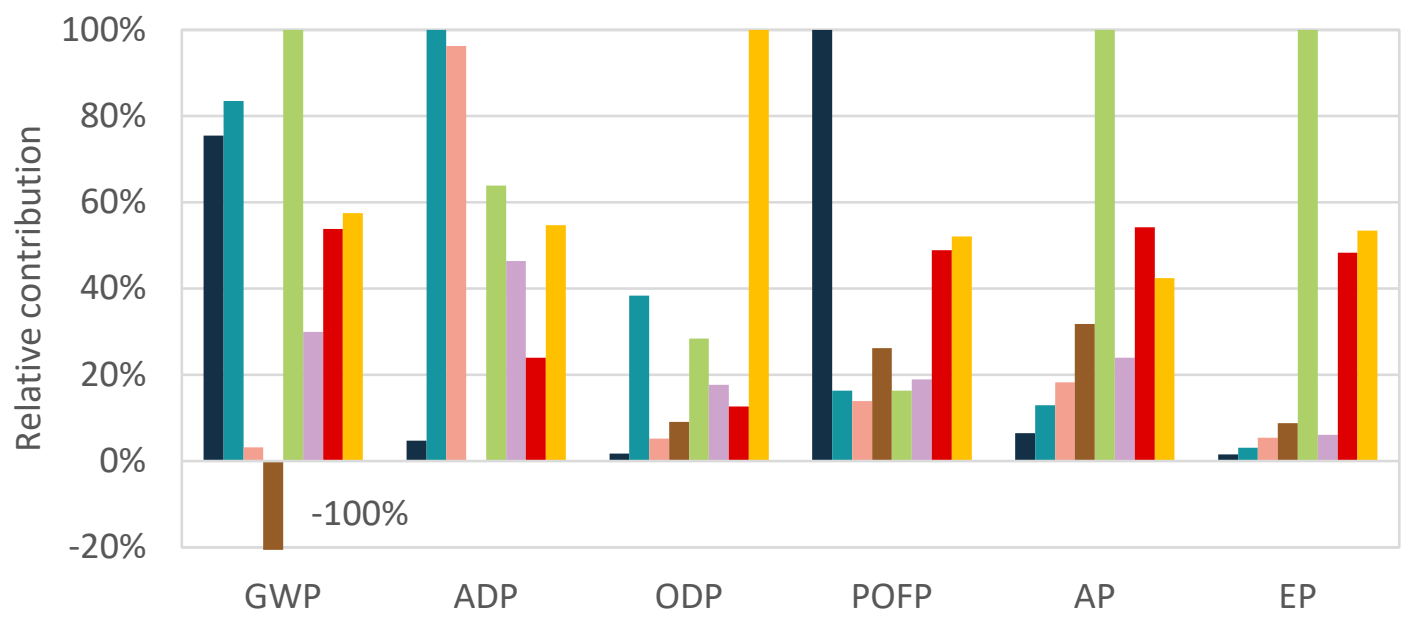

374 Figure 7. Comparison (in \%) of different reforming processes to obtain hydrogen. Caption: Dark

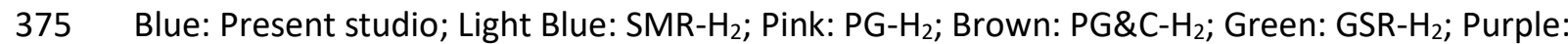

376 BSR-H $\mathrm{H}_{2}$; Red: SBR-H $\mathrm{H}_{2}$; Yellow: BAR- $\mathrm{H}_{2}$.

377 The comparison between the present study and other published processes is possible because

378 the environmental performance of the different studies is published in some LCA studies with

379 a methodological framework consistent with this study. Steam reforming of alcoholic residues

380 has the highest value in POF, due to direct emissions of $\mathrm{CH}_{4}$, which occur in relatively high

381 quantities during steam reforming. However, this process performs well in terms of ODP with a

382 value around $2 \%$ of $\mathrm{BAR}-\mathrm{H}_{2}$, which is the process with the worst environmental performance in

383 this category. 
Four impact categories are detailed in this section: Depletion of abiotic resources (ADP),

Acidification potential (AP), Eutrophication potential (EP) and Global warming potential (GWP).

These are the most common and well-established categories for assessing bioenergy systems

in LCA studies (Cherubini and Strømman, 2011; Muench and Guenther, 2013; Peters et al., 2015). The total GHG emissions of the system are estimated at approximately $9.55 \mathrm{~kg} \mathrm{CO}_{2}$ eq per $\mathrm{kg}$ of $\mathrm{H}_{2}$ produced. As can be seen in Figure 8.a, this value is relatively higher than that of other technologies but is considerably lower than that of a conventional $\mathrm{H}_{2}$ production system $\left(\mathrm{SMR}-\mathrm{H}_{2}\right)$. Approximately $90 \%$ of these emissions are attributed to direct methane emissions from the reforming reactor, as $\mathrm{CH}_{4}$ is 21 times more likely to affect GWP over a 100-year period, according to IPCC. The lowest value in this category corresponds to PG\&G- $\mathrm{H}_{2}$, since this process considers $\mathrm{CO}_{2}$ capture during biomass cultivation. This explains the importance of system boundaries in an LCA study, since PG\&G- $\mathrm{H}_{2}$ covers from biomass cultivation to hydrogen production with $\mathrm{CO}_{2}$ capture. However, in the present study the limit of the system ranges from alcoholic residues entering the plant to the production of electricity, so carbon sequestration during biomass cultivation is not considered.

Some metals, minerals and fossil fuels are used in all $\mathrm{H}_{2}$ production systems. Figure $8 \mathrm{~b}$ shows that fossil methane to hydrogen system $\left(\mathrm{SMR}-\mathrm{H}_{2}\right)$ has the greatest impact on $A D P$, as expected, due to the large consumption of fossil fuels in the reforming process. $\mathrm{H}_{2}$ produced from bioethanol consumes considerable non-renewable resources throughout the life cycle when ethanol production phases are considered (Hajjaji et al., 2013). However, in this study, steam reforming of alcoholic waste (mainly ethanol) is the best process in terms of ADP because this ethanol is a waste derived from another process that has no associated impact. With respect to Acidification Potential and Eutrophication Potential (Figure 8c and 8d), steam reforming of alcoholic waste presents the best results. The processes with the highest impact in these impact categories are those that take into account the cultivation phase $\left(\mathrm{SBR}-\mathrm{H}_{2}, \mathrm{BAR}-\mathrm{H}_{2}\right.$ and 


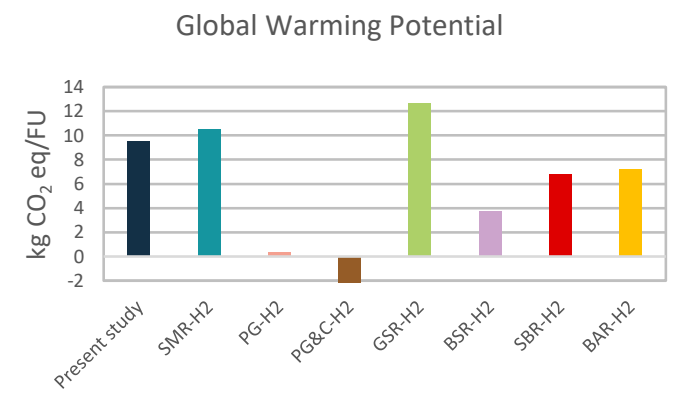

Acidification Potential

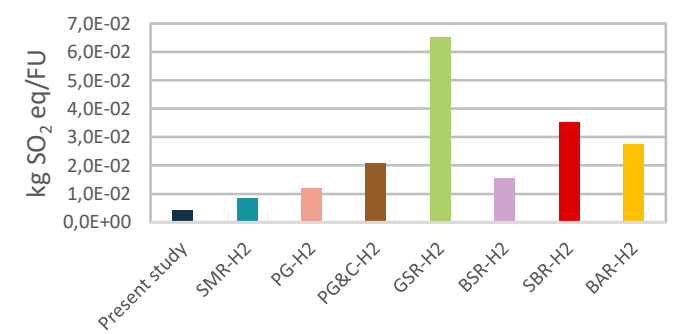

Abiotic Depletion Potential

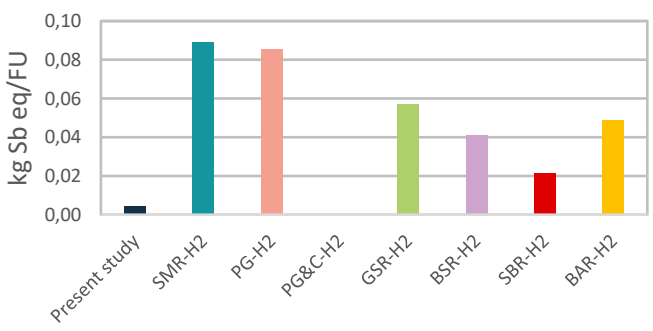

Eutrophication Potential

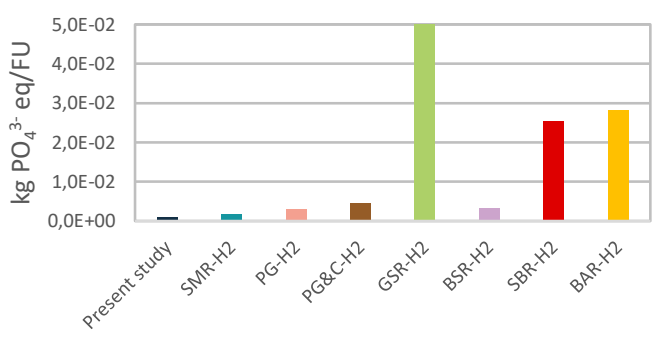

412

Figure 8. Comparison of the environmental impacts in GWP, ADP, AP and EP categories

\section{Conclusions}

From a life cycle perspective, the results suggest that this type of energy systems that produce hydrogen from alcoholic waste through steam reforming has good environmental performance. Overall, steam reforming of this type of alcoholic waste for energy production could play a significant role in future energy systems.

The SOFC is the main contributor to environmental impact in most impact categories.

Analysing the different processes, the manufacture of SOFC is the process with the greatest environmental impact in all impact categories except in $\mathrm{ME}$, where wastewater treatment is the main contributor. The sensitivity analysis shows the promising performance of this waste treatment, since the treatment of 1 tonne of alcoholic waste produces $351 \mathrm{~kg}$ of $\mathrm{CO}_{2}$ eq, this result is $33 \%$ and $30 \%$ better than incineration and sanitary landfill respectively.

It is clear that Life Cycle Assessment is a useful tool to determine the environmental performance of steam reforming of alcoholic waste to produce electricity. However, these 
427 results have been obtained by evaluating the data taken on a laboratory scale, and more

428 studies on a larger scale will be needed in the future to determine a more accurate estimate of 429 the actual environmental profile of the process.

430 Comparative analysis has allowed us to compare this process with others related to the 431 production of hydrogen from different raw materials. Although steam reforming has some 432 poor results in GWP and POF due to methane emissions, its environmental performance is 433 generally better than other processes published in the scientific literature.

\section{Acknowledgements}

This research was supported by the European Projects STAR-ProBio (Grant Agreement Number 727740) and life-ECOELECTRICITY. The authors (Mr. Antonio Cortés, Prof. Gumersindo Feijoo and Prof. Maria Teresa Moreira) belong to the Galician Competitive Research Group GRC ED413C 2017/2019 and to the CRETUS Strategic Partnership (ED431E 2018/01), co-funded by FEDER (EU). Prof. María Teresa Moreira and Prof. Antonio Chica acknowledge to Red de

Excelencia en biorrefinerías sostenibles (CTQ2016-81848-REDT)

\section{References}

Aguilar-Sánchez, P., Navarro-Pineda, F.S., Sacramento-Rivero, J.C., Barahona-Pérez, L.F., 2018.

Alamolhoda, S., Vitale, G., Hassan, A., Nassar, N.N., Almao, P.P., 2019. Synergetic effects of cerium and nickel in Ce-Ni-MFI catalysts on low-temperature water-gas shift reaction. 
syngas production via biomass conversion through the integration of pyrolysis and airsteam gasification processes. Energy Convers. Manag. 87, 670-675. https://doi.org/10.1016/j.enconman.2014.07.065

Anzelmo, B., Wilcox, J., Liguori, S., 2018. Hydrogen production via natural gas steam reforming in a Pd-Au membrane reactor. Investigation of reaction temperature and GHSV effects and long-term stability. J. Memb. Sci. 568, 113-120. https://doi.org/10.1016/j.memsci.2018.09.054

Balat, M., 2011. Production of bioethanol from lignocellulosic materials via the biochemical pathway: A review. Energy Convers. Manag. 52, 858-875. https://doi.org/10.1016/j.enconman.2010.08.013

Braga, A.H., Sodré, E.R., Batista, J., Santos, O., Paula, C.M. De, Maria, J., Bueno, C., 2016. Steam reforming of acetone over $\mathrm{Ni}$ - and Co-based catalysts : Effect of the composition of reactants and catalysts on reaction pathways. Appl. Catal. B, Environ. 195, 16-28. https://doi.org/10.1016/j.apcatb.2016.04.047

Cherubini, F., Strømman, A.H., 2011. Life cycle assessment of bioenergy systems: State of the art and future challenges. Bioresour. Technol. 102, 437-451. https://doi.org/10.1016/j.biortech.2010.08.010

Comité Européen des Enterprises Vins, 2016. European Wine: a solid pillar of the European Union economy. Brussels.

Compagnoni, M., Mostafavi, E., Tripodi, A., Mahinpey, N., Rossetti, I., 2017. Techno-economic Analysis of a Bioethanol to Hydrogen Centralized Plant. Energy and Fuels 31, 1298812996. https://doi.org/10.1021/acs.energyfuels.7b02434

Coronado, I., Pitínová, M., Karinen, R., Reinikainen, M., Puurunen, R.L., Lehtonen, J., 2018. Aqueous-phase reforming of Fischer-Tropsch alcohols over nickel-based catalysts to produce hydrogen: Product distribution and reaction pathways. Appl. Catal. A Gen. 567, 
477 Costa, D., Jesus, J., Virgínio e Silva, J., Silveira, M., 2018. Life Cycle Assessment of Bioethanol 478 Production from Sweet Potato (Ipomoea batatas L.) in an Experimental Plant. Bioenergy Res. 11, 715-725. https://doi.org/10.1007/s12155-018-9932-1

Da Costa-Serra, J.F., Chica, A., 2018. Catalysts based on Co-Birnessite and Co-Todorokite for the efficient production of hydrogen by ethanol steam reforming. Int. J. Hydrogen Energy 43, 16859-16865. https://doi.org/10.1016/j.ijhydene.2017.12.114

Demirbas, A., 2008. Biofuels sources, biofuel policy, biofuel economy and global biofuel projections. Energy Convers. Manag. 49, 2106-2116. https://doi.org/10.1016/j.enconman.2008.02.020

Díaz Alvarado, F., Gracia, F., 2010. Steam reforming of ethanol for hydrogen production: Thermodynamic analysis including different carbon deposits representation. Int. J. Hydrogen Energy 165, 649-657. https://doi.org/10.1016/j.cej.2010.09.051

Esteve-Adell, I., Crapart, B., Primo, A., Serp, P., Garcia, H., 2017. Aqueous phase reforming of glycerol using doped graphenes as metal-free catalysts. Green Chem. 19, 3061-3068. https://doi.org/10.1039/c7gc01058c

Fragiacomo, P., de Lorenzo, G., Corigliano, O., 2018. Performance Analysis of a Solid Oxide Fuel Cell-Gasifier Integrated System in Co-Trigenerative Arrangement. J. Energy Resour. Technol. 140, 092001 (1-9). https://doi.org/10.1115/1.4039872

Frolov, S.M., Medvedev, S.N., Basevich, V.Y., Frolov, F.S., 2013. Self-ignition of hydrocarbonhydrogen-air mixtures. Int. J. Hydrogen Energy 38, 4177-4184. https://doi.org/10.1016/j.ijhydene.2013.01.075

Galera, S., Gutiérrez-Ortiz, F.J., 2015. Life cycle assessment of hydrogen and power production by supercritical water reforming of glycerol. Energy Convers. Manag. 96, 637-645. 
501

García, L., Valiente, A., Oliva, M., Ruiz, J., Arauzo, J., 2018. Influence of operating variables on the aqueous-phase reforming of glycerol over a Ni/Al coprecipitated catalyst. Int. J. Hydrogen Energy 43, 20392-20407. https://doi.org/10.1016/j.ijhydene.2018.09.119

González-García, S., Iribarren, D., Susmozas, A., Dufour, J., Murphy, R.J., 2012. Life cycle assessment of two alternative bioenergy systems involving Salix spp. biomass: Bioethanol production and power generation. Appl. Energy 95, 111-122. https://doi.org/10.1016/j.apenergy.2012.02.022

Hajjaji, N., Khila, Z., Baccar, I., Pons, M.N., 2016. A thermo-environmental study of hydrogen production from the steam reforming of bioethanol. J. Energy Storage 7, 204-219. https://doi.org/10.1016/j.est.2016.06.010

Hajjaji, N., Pons, M.N., Renaudin, V., Houas, A., 2013. Comparative life cycle assessment of eight alternatives for hydrogen production from renewable and fossil feedstock. J. Clean. Prod. 44, 177-189. https://doi.org/10.1016/j.jclepro.2012.11.043

Halleux, H., Lassaux, S., Renzoni, R., Germain, A., 2008. Comparative Life Cycle Assessment of Two Biofuels. Ethanol from Sugar Beet and Rapeseed Methyl Ester. Int. J. Life Cycle Assess. 13, 184-190. https://doi.org/10.1065/lca2008.03.382

Haryanto, A., Fernando, S., Murali, N., Adhikari, S., 2005. Current status of hydrogen production techniques by steam reforming of ethanol: A review. Energy \& Fuels 19, 2098-2106. https://doi.org/10.1021/ef0500538

Hernández, L., Kafarov, V., 2009. Use of bioethanol for sustainable electrical energy production. Int. J. Hydrogen Energy 34, 7041-7050. https://doi.org/10.1016/j.ijhydene.2008.07.089 
ISO, 2006b. ISO 14044 - Environmental Management - Life Cycle Assessment - Requirements and Guidelines. International Organization for Standardization.

Jeon, J., Nam, S., Ko, C.H., 2018. Rapid evaluation of coke resistance in catalysts for methane reforming using low steam-to-carbon ratio. Catal. Today 309, 140-146. https://doi.org/10.1016/j.cattod.2017.08.051

Jeswani, H.K., Falano, T., Azapagic, A., 2015. Life cycle environmental sustainability of lignocellulosic ethanol produced in integrated thermo-chemical biorefineries. Biofuels, Bioprod. Biorefining 9, 661-676. https://doi.org/10.1002/bbb

Karlsson, H., Börjesson, P., Hansson, P.A., Ahlgren, S., 2014. Ethanol production in biorefineries using lignocellulosic feedstock - GHG performance, energy balance and implications of life cycle calculation methodology. J. Clean. Prod. 83, 420-427. https://doi.org/10.1016/j.jclepro.2014.07.029

Khaodee, W., Wongsakulphasatch, S., Kiatkittipong, W., Arpornwichanop, A., Laosiripojana, N., Assabumrungrat, S., 2011. Selection of appropriate primary fuel for hydrogen production for different fuel cell types: Comparison between decomposition and steam reforming. Int. J. Hydrogen Energy 36, 7696-7706. https://doi.org/10.1016/j.ijhydene.2011.03.123

Khila, Z., Baccar, I., Jemel, I., Hajjaji, N., 2017. Thermo-environmental life cycle assessment of hydrogen production by autothermal reforming of bioethanol. Energy Sustain. Dev. 37, 66-78. https://doi.org/10.1016/j.esd.2016.12.003

Khila, Z., Baccar, I., Jemel, I., Houas, A., Hajjaji, N., 2016. Energetic, exergetic and environmental life cycle assessment analyses as tools for optimization of hydrogen production by autothermal reforming of bioethanol. Int. J. Hydrogen Energy 41, 1772317739. https://doi.org/10.1016/j.ijhydene.2016.07.225 
Kumar, B., Kumar, S., Sinha, S., Kumar, S., 2018. Utilization of acetone-butanol-ethanol-water mixture obtained from biomass fermentation as renewable feedstock for hydrogen production via steam reforming: Thermodynamic and energy analyses. Bioresour. Technol. 261, 385-393. https://doi.org/10.1016/j.biortech.2018.04.035

Lee, Y.D., Ahn, K.Y., Morosuk, T., Tsatsaronis, G., 2015. Environmental impact assessment of a solid-oxide fuel-cell-based combined-heat-and-power-generation system. Energy 79, 455-466. https://doi.org/10.1016/j.energy.2014.11.035

López, E.R., Dorado, F., de Lucas-Consuegra, A., 2019. Electrochemical promotion for hydrogen production via ethanol steam reforming reaction. Appl. Catal. B Environ. 243, 355-364. https://doi.org/10.1016/j.apcatb.2018.10.062

Luo, L., van der Voet, E., Huppes, G., 2009. Life cycle assessment and life cycle costing of bioethanol from sugarcane in Brazil. Renew. Sustain. Energy Rev. 13, 1613-1619. https://doi.org/10.1016/j.rser.2008.09.024

Menezes, J., Manfro, R., Souza, M., 2018. Hydrogen production from glycerol steam reforming over nickel catalysts supported on alumina and niobia: Deactivation process, effect of reaction conditions and kinetic modeling. Int. J. Hydrogen Energy 43, 15064-15082. https://doi.org/10.1016/j.ijhydene.2018.06.048

Menor, M., Sayas, S., Chica, A., 2017. Natural sepiolite promoted with $\mathrm{Ni}$ as new and efficient catalyst for the sustainable production of hydrogen by steam reforming of the biodiesel by-products glycerol. Fuel 193, 351-358. https://doi.org/10.1016/j.fuel.2016.12.068

Morales, M., Roa, J.J., Capdevila, X.G., Segarra, M., Piñol, S., 2010. Mechanical properties at the nanometer scale of GDC and YSZ used as electrolytes for solid oxide fuel cells. Acta Mater. 58, 2504-2509. https://doi.org/10.1016/j.actamat.2009.12.036

Muench, S., Guenther, E., 2013. A systematic review of bioenergy life cycle assessments. Appl. Energy 112, 257-273. https://doi.org/10.1016/j.apenergy.2013.06.001 
$573 \mathrm{Ni}$, M., Leung, D.Y.C., Leung, M.K.H., 2007. A review on reforming bio-ethanol for hydrogen

$574 \quad$ production. Int. J. Hydrogen Energy 32, 3238-3247.

$575 \quad$ https://doi.org/10.1016/j.ijhydene.2007.04.038

576 Peters, J.F., Iribarren, D., Dufour, J., 2015. Simulation and life cycle assessment of biofuel

577 production via fast pyrolysis and hydroupgrading. Fuel 139, 441-456.

578 https://doi.org/https://doi.org/10.1016/j.fuel.2014.09.014

PRé Consultants, 2017. SimaPro Database Manual (No. Methods Library). The Netherlands.

580

581

582

583

584

585

586

587

588

589

590

591

592

593

594

595

596

Rabenstein, G., Hacker, V., 2008. Hydrogen for fuel cells from ethanol by steam-reforming, partial-oxidation and combined auto-thermal reforming: A thermodynamic analysis. J. Power Sources 185, 1293-1304. https://doi.org/10.1016/j.jpowsour.2008.08.010

Ramírez, P., Homs, N., 2008. Use of biofuels to produce hydrogen (reformation processes). Chem. Soc. Rev. 37, 2459-2467. https://doi.org/10.1039/b712181b

Reyes-Valle, C., Villanueva-Perales, A.L., Vidal-Barrero, F., Ollero, P., 2015. Integrated economic and life cycle assessment of thermochemical production of bioethanol to reduce production cost by exploiting excess of greenhouse gas savings. Appl. Energy 148, 466475. https://doi.org/10.1016/j.apenergy.2015.03.113

Rossetti, I., Compagnoni, M., Torli, M., 2015a. Process simulation and optimization of H2 production from ethanol steam reforming and its use in fuel cells. 1. Thermodynamic and kinetic analysis. Chem. Eng. J. 281, 1024-1035. https://doi.org/10.1016/j.cej.2015.08.045

Rossetti, I., Compagnoni, M., Torli, M., 2015b. Process simulation and optimization of H2 production from ethanol steam reforming and its use in fuel cells. 2. Process analysis and optimization. Chem. Eng. J. 281, 1036-1044. https://doi.org/10.1016/j.cej.2015.08.045

Salkuyeh, Y.K., Saville, B.A., MacLean, H.L., 2018. Techno-economic analysis and life cycle assessment of hydrogen production from different biomass gasification processes. Int. J. 
598

Spallina, V., Matturro, G., Ruocco, C., Meloni, E., Palma, V., Fernandez, E., Melendez, J., Pacheco-Tanaka, A.D., Viviente-Sole, J.L., van Sint-Annaland, M., Gallucci, F., 2018. Direct route from ethanol to pure hydrogen through autothermal reforming in a membrane reactor: Experimental demonstration, reactor modelling and design. Energy 143, 666681. https://doi.org/10.1016/j.energy.2017.11.031

Spath, P.L., Mann, M.K., 2001. Life cycle assessment of hydrogen production via natural gas steam reforming, National Renewable Energy Laboratory.

Spiridon, I., Darie-Nita, R.N., Hitruc, G.E., Ludwiczak, J., Cianga, I.A., Niculaua, M., 2016. New opportunities to valorize biomass wastes into green materials. J. Clean. Prod. 133, 235242. https://doi.org/10.1016/j.jclepro.2016.05.143

Strazza, C., Del Borghi, A., Costamagna, P., Gallo, M., Brignole, E., Girdinio, P., 2015. Life Cycle Assessment and Life Cycle Costing of a SOFC system for distributed power generation. Energy Convers. Manag. 100, 64-77. https://doi.org/10.1016/j.enconman.2015.04.068

Strazza, C., Del Borghi, A., Costamagna, P., Traverso, A., Santin, M., 2010. Comparative LCA of methanol-fuelled SOFCs as auxiliary power systems on-board ships. Appl. Energy 87, 1670-1678. https://doi.org/10.1016/j.apenergy.2009.10.012

Susmozas, A., Iribarren, D., Dufour, J., 2015. Assessing the Life-Cycle Performance of Hydrogen Production via Biofuel Reforming in Europe. Resources 4, 398-411. https://doi.org/10.3390/resources4020398

Susmozas, A., Iribarren, D., Dufour, J., 2013. Life-cycle performance of indirect biomass gasification as a green alternative to steam methane reforming for hydrogen production. Int. J. Hydrogen Energy 38, 9961-9972. https://doi.org/10.1016/j.ijhydene.2013.06.012 Susmozas, A., Iribarren, D., Zapp, P., Linßen, J., Dufour, J., 2016. Life-cycle performance of 

hydrogen production via indirect biomass gasification with CO2 capture. Int. J. Hydrogen Energy 41, 19484-19491. https://doi.org/10.1016/j.ijhydene.2016.02.053

Tian, J., Ke, Y., Kong, G., Tan, M., Wang, Y., Lin, J., Zhou, W., Wan, S., 2017. A novel structured $\mathrm{PdZnAl} / \mathrm{Cu}$ fiber catalyst for methanol steam reforming in microreactor. Renew. Energy 113, 30-42. https://doi.org/10.1016/j.renene.2017.04.070

Tian, Y., Zhou, X., Lin, S., Ji, X., Bai, J., Xu, M., 2018. Syngas production from air-steam gasification of biomass with natural catalysts. Sci. Total Environ. 645, 518-523. https://doi.org/10.1016/j.scitotenv.2018.07.071

Unrean, P., Lai Fui, B.C., Rianawati, E., Acda, M., 2018. Comparative techno-economic assessment and environmental impacts of rice husk-to-fuel conversion technologies. Energy 151, 581-593. https://doi.org/10.1016/j.energy.2018.03.112

Uusitalo, V., Väisänen, S., Inkeri, E., Soukka, R., 2017. Potential for greenhouse gas emission reductions using surplus electricity in hydrogen, methane and methanol production via electrolysis. Energy Convers. Manag. 134, 125-134. https://doi.org/10.1016/j.enconman.2016.12.031

Valente, A., Iribarren, D., Gálvez-Martos, J.L., Dufour, J., 2019. Robust eco-efficiency assessment of hydrogen from biomass gasification as an alternative to conventional hydrogen: A life-cycle study with and without external costs. Sci. Total Environ. 650, 1465-1475. https://doi.org/10.1016/j.scitotenv.2018.09.089

Wang, M., Au, C.T., Lai, S.Y., 2015. H2 production from catalytic steam reforming of n-propanol over ruthenium and ruthenium-nickel bimetallic catalysts supported on ceria-alumina oxides with different ceria loadings. Int. J. Hydrogen Energy 40, 13926-13935. https://doi.org/10.1016/j.ijhydene.2015.07.162

Xue, Z., Shen, Y., Zhu, S., Li, P., Zeng, Y., Xi, Z., Cai, Y., 2017. Autothermal reforming of ethyl acetate for hydrogen production over Ni3La7Oy/Al2O3catalyst. Energy Convers. Manag. 
647 Zheng, T., Zhou, W., Yu, W., Ke, Y., Liu, Y., Liu, R., San Hui, K., 2019. Methanol steam reforming 648 performance optimisation of cylindrical microreactor for hydrogen production utilising 649 error backpropagation and genetic algorithm. Chem. Eng. J. 357, 641-654.

650 https://doi.org/10.1016/j.cej.2018.09.129

651 